\title{
Effect of compositional and environmental factors on the growth of indigenous non-starter lactic acid bacteria in Cheddar cheese*
}

\author{
CN Lane**, PF Fox, EM Walsh, B Folkertsma, PLH McSweeney
}

Department of Food Chemistry, University College, Cork, Ireland

\begin{abstract}
Summary - The effects of salt and moisture content, ripening temperature and starter strain, independently, on the growth of indigenous non-starter lactic acid bacteria (NSLAB) in Cheddar cheeses were studied. Salt-in-moisture (S/M) $\leq 5.9 \%$ had no effect on the growth of NSLAB; $6.1 \%$ S/M reduced their growth rate but had no effect on their number at 6 months. Cheeses with a moisture content $>40.3 \%$ had higher numbers of NSLAB than cheeses with a lower moisture content during the initial stages of ripening; the difference appeared to be related to the length of the lag phase rather than to the rate of growth of these bacteria. Numbers of NSLAB were quite low in cheeses ripened at $4{ }^{\circ} \mathrm{C}$ even after 6 months and increased with ripening temperature at all stages of ripening. NSLAB grew faster initially in cheeses made with Lactococcus lactis ssp lactis ML 3 or 303 as starter than in those made with Lc lactis ssp cremoris AM1 or AM2 but reached similar numbers after 6 months.
\end{abstract}

non-starter lactic acid bacteria / Cheddar cheese / Cheddar cheese composition

Résumé - Effet des facteurs composition et environnement sur la croissance des bactéries lactiques indigènes non levains dans le fromage cheddar. Les effets respectifs de la teneur en sel et en eau, de la température d'affinage et des souches de levains lactiques sur la croissance des bactéries lactiques indigènes non levains (NSLAB) ont été étudiés dans du fromage de cheddar. Le rapport sel/humidité (S/H), inférieur ou égal à 5,9\%, n'a pas d'effet sur la croissance des NSLAB, une teneur à $6,1 \%$ de $\mathrm{S} / \mathrm{H}$ réduit leur taux de croissance mais n'a pas d'effet sur leur nombre à 6 mois d'affinage. Les fromages ayant un taux d'humidité supérieur à $40,3 \%$ ont un plus grand nombre de NSLAB que les fromages ayant un taux d'humidité plus faible durant la phase initiale d'affinage. La différence semble être liée à la durée de la phase de latence, plutôt qu'au taux de croissance de ces bactéries. Les nombres de NSLAB sont plutôt bas dans des fromages affinés à $4{ }^{\circ} \mathrm{C}$, même après 6 mois d'affinage, et croissent en même temps que la température à tous les stades de l'affinage. Le taux de NSLAB augmente initialement plus vite dans des fromages faits avec des Lactococcus lactis spp lactis ML3 ou 303 utilisés en tant que levains comparés à ceux fabriqués avec des Lactococcus lactis spp cremoris AM1 ou AM2, mais atteignent le même taux après 6 mois d'affinage.

bactérie lactique non levain / fromage / cheddar

\footnotetext{
* Oral communication at the IDF Symposium 'Ripening and Quality of Cheeses', Besançon, France, February 26-28, 1996

** Correspondence and reprints
} 


\section{INTRODUCTION}

Non-starter lactic acid bacteria (NSLAB) in Cheddar cheese are adventitious microorganisms, introduced mainly by post-pasteurisation contamination and capable of growing in cheese during ripening. In contrast to starter bacteria, the numbers of which decrease after manufacture at a rate which is strain-dependent, NSLAB grow from low numbers $\left(<10^{1} \mathrm{cfu} / \mathrm{g}\right)$ in fresh curd to dominate the viable microflora of mature Cheddar cheese. Mesophilic lactobacilli are the predominant NSLAB in Irish Cheddar (Jordan and Cogan, 1993); strains typically found include $L b$ casei, $L b$ plantarum, $L b$ pseudoplantarum, Lb curvatus and $\mathrm{Lb}$ brevis. Since lactobacilli have a complex proteolytic system (Peterson and Marshall, 1990; Kanawjia et al, 1993), they may play a role in proteolysis during cheese maturation and hence affect the quality of the final product. While many authors agree that NSLAB may affect the flavour of cheese, some consider this effect to be undesirable (Kleter, 1977) while others suggest that these bacteria contribute to the development of a strong flavour which may be attractive to some consumers (McSweeney et al, 1993). NSLAB have also been associated with defects such as calcium D-lactate crystals on the cheese surface (Khalid and Marth, 1990).

Since NSLAB grow in cheese during ripening, while the numbers of most other bacteria decline, cheese must contain substrates for their growth. Potential growth substrates include lactose, lactate, citrate, sugars from enzymatic hydrolysis of $\kappa$ casein, pyruvate, free amino acids, peptides and starter cell lysate (Peterson and Marshall, 1990; Martley and Crow, 1993). However, the actual substrates used by NSLAB in Cheddar cheese have not been elucidated. In addition to available substrates, it is probable that cheese composition (ie, $\mathrm{pH}$, salt concentration, moisture content) influences the rate and extent of growth of NSLAB; however, very little research on this subject has been reported. Temperature is a major factor controlling bacterial growth in all cheese types. The increased rate of growth of NSLAB in Cheddar cheese at elevated ripening temperatures has been demonstrated (Cromie et al, 1987; Folkertsma et al, 1996).

The effects of the salt and moisture content of Cheddar cheese, ripening temperature and starter strain on the growth of indigenous NSLAB during ripening were investigated in this study.

\section{MATERIALS AND METHODS}

\section{Cultures}

Lactococcus lactis ssp cremoris 223, Lc lactis ssp cremoris AM1, Lc lactis ssp cremoris AM2, Lc lactis ssp lactis ML3 (also named NCDO 763) and Lc lactis ssp lactis 303 were obtained from the culture collection of the Department of Microbiology, University College, Cork. Frozen cultures $(1 \%, v / v)$ were propagated at $30^{\circ} \mathrm{C}$ for $16 \mathrm{~h}$ in autoclaved $\left(110^{\circ} \mathrm{C}, 10 \mathrm{~min}\right)$ reconstituted skim-milk powder $\left(100 \mathrm{~g} \mathrm{~L}^{-1}\right)$. Two transfers were made prior to cheesemaking; bulk cultures were grown for $16 \mathrm{~h}$ at $21^{\circ} \mathrm{C}$.

\section{Standard cheesemaking protocol}

Cheddar cheese was made in a pilot-plant by conventional methods from pasteurised $\left(74^{\circ} \mathrm{C}\right.$, 15 s) bulk milk using $2 \%(\mathrm{v} / \mathrm{v})$ Lc lactis ssp cremoris 223 as starter (unless otherwise stated). Calf rennet (Chr Hansen's Laboratory, Little Island, Cork) was added to the cheesemilk at a level of $0.3 \mathrm{~mL} \mathrm{~L}^{-1}$. The setting temperature was $30^{\circ} \mathrm{C}$ and the coagulum was cut $\sim 50 \mathrm{~min}$ after renneting. The curds were cooked at $39^{\circ} \mathrm{C}$ and cheddared until the $\mathrm{pH}$ reached 5.3-5.4. Unless otherwise stated, milled curds were salted at a level of $2.5 \%(\mathrm{w} / \mathrm{w})$, pressed overnight at 1 bar at $16 \pm 1{ }^{\circ} \mathrm{C}$, vacuum packed and ripened at $8^{\circ} \mathrm{C}$ for 6 months. All cheese trials were carried out in duplicate.

The cheesemaking protocol was modified to manufacture cheeses with varying salt or mois- 
ture content, with different starter strains or different ripening temperature as follows.

\section{Salt content}

Curd $(10 \mathrm{~kg})$ prepared as above was divided after cheddaring into six $1.7-\mathrm{kg}$ lots and salted at a level of $1.5,2.1,2.7,3.3,3.9$ or $4.5 \%(w / w)$.

\section{Moisture content}

It was found that the most successful method for preparing cheese of different moisture content was to salt the curd at different $\mathrm{pH}$ values; $2-\mathrm{kg}$ lots of curd were taken at $\mathrm{pH} 5.9,5.7,5.5,5.3$ or 5.1 , milled, salted at $2.5 \%(\mathrm{w} / \mathrm{w})$ and pressed as described above.

\section{Ripening temperature}

Curd was divided into three $2-\mathrm{kg}$ blocks, salted at $2.5 \%(\mathrm{w} / \mathrm{w})$, pressed overnight at $16 \pm 1{ }^{\circ} \mathrm{C}$, vacuum packed and ripened at 4,8 or $12{ }^{\circ} \mathrm{C}$.

\section{Starter strain}

Cheese $(2 \mathrm{~kg}$ ) was made by the conventional method described above using $2 \%(\mathrm{v} / \mathrm{v}) \mathrm{Lc} \mathrm{lac}$ tis ssp cremoris AM1, Lc lactis ssp cremoris
AM2, Lc lactis ssp lactis ML3 or Lc lactis ssp lactis 303 as starter.

\section{Bacteriological analysis}

Total bacteria in the cheeses were enumerated on LM17 agar (Terzaghi and Sandine, 1975) after incubation at $30^{\circ} \mathrm{C}$ for 3 days. Growth of NSLAB in the cheeses during ripening was estimated by enumeration on Rogosa agar (Rogosa et al, 1951) after incubation at $37^{\circ} \mathrm{C}$ for 5 days.

\section{Compositional analysis}

Samples of each cheese were taken immediately after pressing for duplicate determination of protein (IDF, 1964), fat (IIRS, 1955), moisture (IDF, 1982) and salt (Fox, 1963). The pH of grated cheese $(10 \mathrm{~g})$ macerated in $10 \mathrm{~mL}$ distilled water was measured.

\section{RESULTS}

\section{Effect of salt}

The composition of the experimental Cheddar cheeses is shown in table I. During

Table I. Composition ${ }^{1}$ of 1-day-old experimental cheeses manufactured to give varying salt contents. Composition ${ }^{1}$ de fromages expérimentaux à 1 jour, fabriqués avec différentes teneurs en sel.

\begin{tabular}{lcccccc}
\hline $\begin{array}{l}\text { Salting level } \\
(\%)\end{array}$ & $\begin{array}{c}\text { Salt } \\
(\%)\end{array}$ & $\begin{array}{c}\text { Moisture } \\
(\%)\end{array}$ & $\begin{array}{c}S / M^{2} \\
(\%)\end{array}$ & $\begin{array}{c}\text { Fat } \\
(\%)\end{array}$ & $\begin{array}{c}\text { Protein } \\
(\%)\end{array}$ & $\begin{array}{c}p H \\
(\%)\end{array}$ \\
\hline $\begin{array}{l}\text { Trial I } \\
1.5\end{array}$ & 1.13 & 39.6 & 2.85 & 29.8 & 25.0 & 5.23 \\
2.1 & 1.38 & 38.6 & 3.58 & 30.0 & 24.7 & 5.26 \\
2.7 & 1.59 & 39.5 & 4.03 & 29.5 & 24.7 & 5.32 \\
3.3 & 1.70 & 39.9 & 4.26 & 30.0 & 25.0 & 5.33 \\
3.9 & 1.77 & 38.5 & 4.60 & 29.8 & 25.3 & 5.34 \\
4.5 & 2.05 & 38.2 & 5.37 & 29.8 & 25.6 & 5.37 \\
Trial 2 & & & & & & \\
1.5 & 1.19 & 38.6 & 3.08 & 33.0 & 24.7 & 5.18 \\
2.1 & 1.57 & 37.3 & 4.21 & 33.0 & 25.3 & 5.27 \\
2.7 & 1.84 & 35.7 & 5.15 & 33.0 & 26.1 & 5.33 \\
3.3 & 1.94 & 36.1 & 5.37 & 34.3 & 25.7 & 5.34 \\
3.9 & 2.04 & 34.4 & 5.93 & 33.5 & 26.5 & 5.39 \\
4.5 & 2.10 & 34.5 & 6.09 & 33.0 & 26.6 & 5.39 \\
\hline
\end{tabular}

\footnotetext{
${ }^{1}$ Mean of duplicates. ${ }^{2}$ Salt-in-moisture.

${ }^{I}$ Moyenne de deux déterminations. ${ }^{2}$ Rapport sel/humidité.
} 
manufacture, curds were salted at levels from 1.5 to $4.5 \%(\mathrm{w} / \mathrm{w})$ at $0.6 \%$ increments, resulting in cheeses with a salt content ranging from 1.13 to $2.05 \%$ (trial 1) and from 1.19 to $2.10 \%$ (trial 2). The moisture content of the cheeses generally decreased with increasing salt content (especially in trial 2 ). Since the concentration of salt in the aqueous phase, rather than the total salt content, is an important parameter for the growth of bacteria in cheese, the salt content was expressed as salt-in-cheese moisture
(S/M). The $\mathrm{pH}$ of the cheeses increased with increasing salt content, ranging from 5.23 to 5.37 in trial 1 and 5.18 to 5.39 in trial 2 .

Starter bacteria were enumerated on LM17 agar but NSLAB can also grow on this medium and, if present in sufficiently large numbers, will cause overestimation of starter bacteria. To avoid this, counts on LM17 during the early stages of ripening only (when the numbers of NSLAB were low) were considered to be a valid estimation of starter numbers. Immediately after

Table II. Changes in starter population in experimental cheeses during the early stages of ripening. Changement de population des levains dans des fromages expérimentaux pendant les premières phases d'affinage.

\begin{tabular}{|c|c|c|c|c|c|c|c|c|}
\hline \multirow[t]{3}{*}{ Cheese type } & \multicolumn{8}{|c|}{ Ripening time (weeks) } \\
\hline & 0 & 1 & 3 & 4 & 0 & 1 & 3 & 4 \\
\hline & \multicolumn{3}{|c|}{ Trial 1} & \multicolumn{3}{|c|}{$\log c f u g^{-1}$ cheese } & & \\
\hline \multicolumn{9}{|c|}{ Salting level (\%) } \\
\hline 1.5 & 8.0 & 7.3 & 7.6 & 7.2 & 8.0 & 7.2 & 6.4 & 6.0 \\
\hline 2.1 & 8.1 & 6.8 & 7.3 & 7.2 & 8.0 & 6.9 & 5.9 & 5.8 \\
\hline 2.7 & 8.2 & 7.0 & 7.0 & 7.0 & 8.0 & 6.9 & 6.1 & 5.8 \\
\hline 3.3 & 8.2 & 7.0 & 7.0 & 6.4 & 8.1 & 7.3 & 6.0 & 6.0 \\
\hline 3.9 & 8.0 & 7.0 & 6.3 & 6.1 & 8.0 & 5.5 & 5.6 & 6.0 \\
\hline 4.5 & 8.0 & 7.4 & 6.6 & 6.1 & 8.0 & 6.2 & 5.6 & 6.4 \\
\hline \multicolumn{9}{|l|}{ Milling $\mathrm{pH}$} \\
\hline 5.1 & 7.2 & ND & 6.5 & 6.3 & 7.2 & 6.9 & 6.5 & 6.4 \\
\hline 5.3 & 7.5 & ND & 6.9 & 6.4 & 7.9 & 6.5 & 6.3 & 6.6 \\
\hline 5.5 & 7.7 & ND & 6.7 & 6.4 & 7.7 & 6.9 & 6.5 & 6.8 \\
\hline 5.7 & 7.2 & ND & 6.7 & 6.2 & 7.3 & 6.8 & 7.1 & 8.0 \\
\hline 5.9 & 7.4 & ND & 6.8 & 6.3 & 7.9 & 7.0 & 7.9 & 8.3 \\
\hline \multicolumn{9}{|c|}{$\begin{array}{l}\text { Ripening } \\
\text { temperature }\left({ }^{\circ} \mathrm{C}\right)\end{array}$} \\
\hline 4 & 8.0 & 7.0 & 6.5 & 5.9 & 7.1 & 6.9 & 6.4 & 5.3 \\
\hline 8 & 8.0 & 6.8 & 6.3 & 5.9 & 7.1 & 7.0 & 7.3 & 6.5 \\
\hline 12 & 8.0 & 6.5 & 6.3 & 5.4 & 7.1 & 6.5 & 5.9 & 5.6 \\
\hline \multicolumn{9}{|l|}{ Starter strain } \\
\hline AM1 & 5.6 & 5.6 & 6.5 & 6.0 & 6.4 & 6.7 & 6.0 & 6.2 \\
\hline $\mathrm{AM} 2$ & 5.4 & ND & 4.8 & 4.5 & 4.7 & 4.6 & ND & 5.7 \\
\hline ML3 & 9.1 & 9.2 & 7.6 & 8.1 & 8.6 & 7.2 & ND & 7.4 \\
\hline 303 & 9.6 & 9.9 & 9.6 & 9.5 & 9.6 & 9.6 & 9.6 & 9.4 \\
\hline
\end{tabular}

$\mathrm{ND}$, not determined.

$N D$ : non déterminé. 
pressing, starter counts were between 1.0 and $1.5 \times 10^{8} \mathrm{cfu} \mathrm{g}^{-1}$ cheese in trial 1 and 1.0 and $1.2 \times 10^{8} \mathrm{cfu}^{-1}$ in trial 2 and the rate at which they decreased over the next few weeks appeared to be independent of the $\mathrm{S} / \mathrm{M}$ in the cheeses (table II).

NSLAB were not detected in the cheeses at one day but grew in all cheeses during ripening, reaching numbers from $4.8 \times 10^{7}$ to $2.5 \times 10^{8} \mathrm{cfu} \mathrm{g}^{-1}$ in trial 1 and from $3.5 \times 10^{7}$ to $1.5 \times 10^{8} \mathrm{cfu} \mathrm{g}^{-1}$ in trial 2 after 6 months (fig 1A, B). S/M levels of 2.85 to $5.37 \%$ in the experimental cheeses in trial 1 had no effect on the rate at which NSLAB grew in the cheese (fig 1A). In trial 2, differences in NSLAB numbers during ripening in cheeses with $\mathrm{S} / \mathrm{M}$ levels $\leq 5.93 \% \mathrm{did}$ not appear to be related to increasing S/M
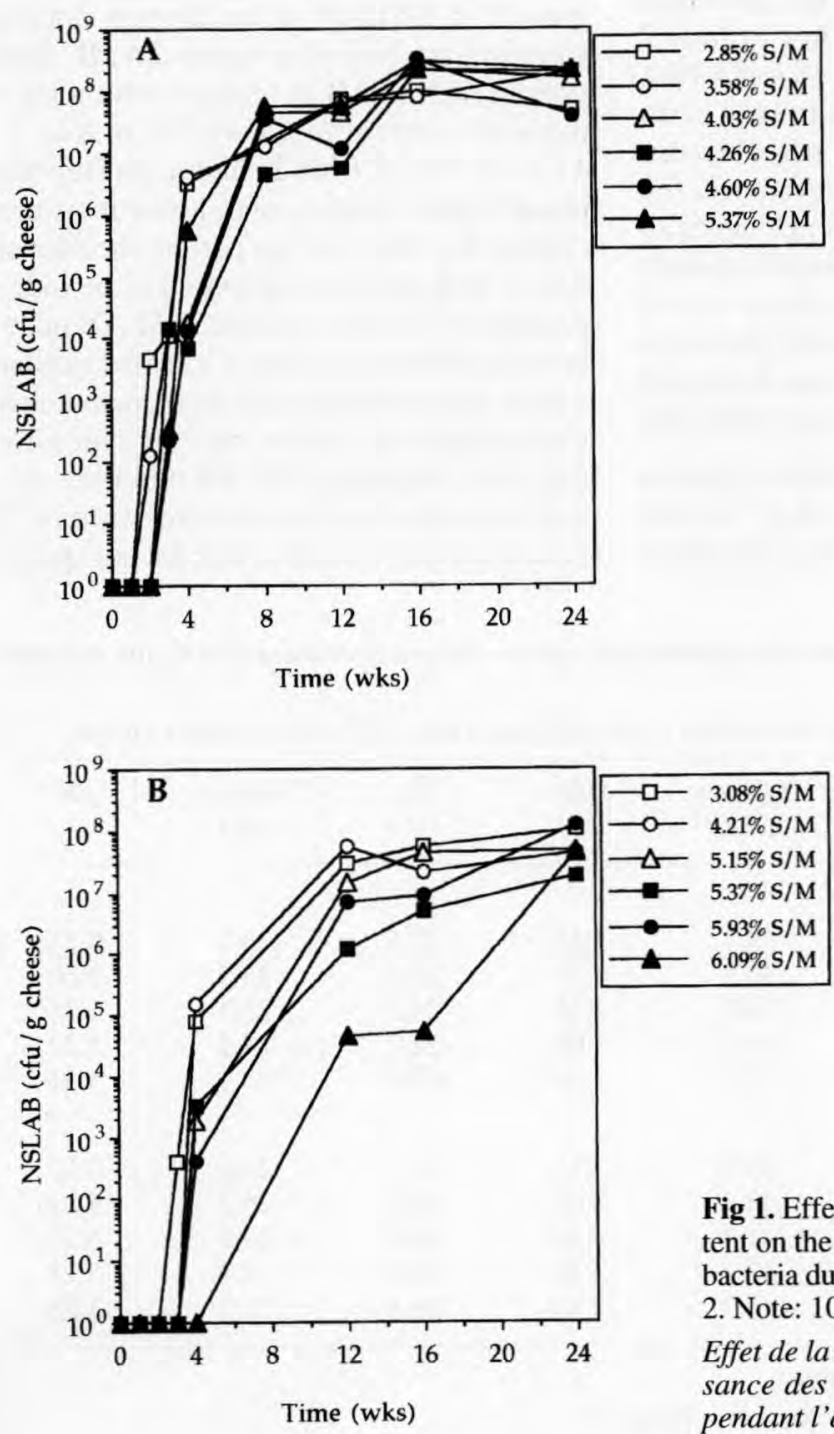

Fig 1. Effect of salt-in-moisture (S/M) content on the growth of non-starter lactic acid bacteria during ripening. A. Trial 1. B. Trial 2 . Note: $10^{0} \approx<10$ cfu NSLAB g ${ }^{-1}$ cheese. Effet de la teneur sel/humidité sur la croissance des bactéries lactiques non levains pendant l'affinage. A. Essai 1. B. Essai 2. 
content (Fig 1B); in the cheese with the highest S/M level (ie, 6.09\%), NSLAB grew slowly to $5.5 \times 10^{4} \mathrm{cfu} \mathrm{g}^{-1}$ at 4 months. NSLAB in all cheeses in trial 2 were similar at 6 months (fig 1B).

\section{Effect of moisture}

The composition of the experimental Cheddar cheeses is shown in table III. The range of moisture levels was higher in trial 2 $(39.2-45.0 \%)$ than in trial $1(38.4-43.7 \%)$. The $\mathrm{pH}$ of the cheeses increased with increasing moisture content, probably due to the fact that, during manufacture, the curds were milled at different $\mathrm{pH}$ values so that cheeses varying in moisture content could be produced. Salt content varied between the cheeses in each trial. The levels of fat and protein in the cheeses decreased with increasing moisture content (table III).

Starter numbers in the cheeses express ranges from 1.7 to $4.5 \times 10^{7} \mathrm{cfu} \mathrm{g}^{-1}$ in trial 1 and from 1.4 to $7.7 \times 10^{7} \mathrm{cfu} \mathrm{g}^{-1}$ in trial 2 and generally decreased by approximately one log cycle after 4 weeks (table II). The high starter numbers after 4 weeks ripening in the cheeses in trial 2 with a moisture content of 42.9 or $45.0 \%$ may indicate contamination by non-starter micro-organisms; NSLAB counts in these cheeses were $1.5 \times 10^{7}$ and $1.9 \times 10^{6} \mathrm{cfu} \mathrm{g}^{-1}$, respectively, after 4 weeks (fig $2 \mathrm{~B}$ ).

The effect of moisture content on the growth of NSLAB in the cheeses during ripening is shown in figure $2 \mathrm{~A}, \mathrm{~B}$. The growth of NSLAB in cheeses with a high moisture content $(39.7-43.7 \%$ in trial 1 , $41.3-45.0 \%$ in trial 2) had a shorter lag phase than in cheeses with lower moisture content but after the lag period, the rate at which NSLAB grew appeared to be independent of moisture content. NSLAB numbers in all cheeses in trial 1 reached similar values after 3 months and were maintained throughout the latter half of ripening (fig 2A). Although NSLAB numbers varied between the five cheeses in trial 2 between 2 and 4 months, this did not appear

Table III. Composition ${ }^{1}$ of 1-day-old experimental cheeses manufactured to give varying moisture contents.

Composition ${ }^{1}$ de fromages expérimentaux à 1 jour, fabriqués avec différentes teneurs en eau.

\begin{tabular}{ccccccc}
\hline Milling $\mathrm{pH}$ & $\begin{array}{c}\text { Salt } \\
(\%)\end{array}$ & $\begin{array}{c}\text { Moisture } \\
(\%)\end{array}$ & $\begin{array}{c}\text { S/M } \\
(\%)\end{array}$ & $\begin{array}{c}\text { Fat } \\
(\%)\end{array}$ & $\begin{array}{c}\text { Protein } \\
(\%)\end{array}$ & $p H$ \\
\hline Trial 1 & & & & & & \\
5.1 & 1.36 & 38.4 & 3.54 & 30.5 & 26.1 & 5.23 \\
5.3 & 1.63 & 38.5 & 4.23 & 30.0 & 25.5 & 5.30 \\
5.5 & 1.73 & 39.7 & 4.36 & 29.5 & 25.3 & 5.38 \\
5.7 & 1.66 & 41.4 & 4.01 & 28.0 & 24.5 & 5.37 \\
5.9 & 1.69 & 43.7 & 3.87 & 26.8 & 23.9 & 5.44 \\
Trial 2 & & & & & & \\
5.1 & 1.47 & 39.2 & 3.75 & 33.3 & 26.0 & 5.10 \\
5.3 & 1.48 & 40.3 & 3.67 & 29.5 & 25.2 & 5.12 \\
5.5 & 1.38 & 41.3 & 3.34 & 29.0 & 24.6 & 5.15 \\
5.7 & 1.37 & 42.9 & 3.19 & 29.0 & 24.2 & 5.17 \\
5.9 & 1.68 & 45.0 & 3.73 & 26.8 & 23.2 & 5.23 \\
\hline
\end{tabular}

${ }^{1}$ Mean of duplicates. ${ }^{2}$ Salt-in-moisture.

${ }^{1}$ Moyenne de deux déterminations. ${ }^{2}$ Rapport sel/humidité. 

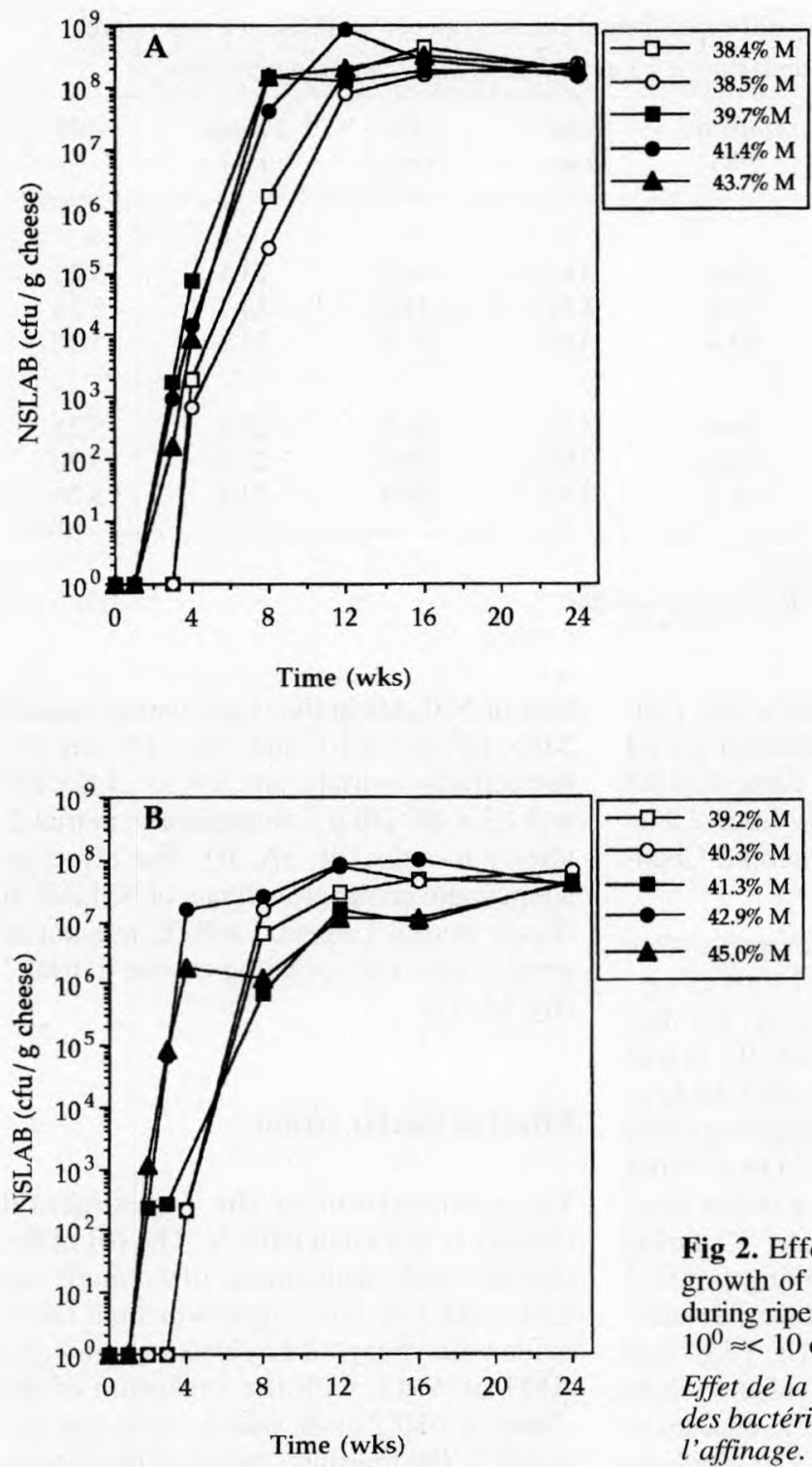

Fig 2. Effect of moisture content on the growth of non-starter lactic acid bacteria during ripening. A. Trial 1. B. Trial 2. Note: $10^{0} \approx<10$ cfu NSLAB g ${ }^{-1}$ cheese.

Effet de la teneur en eau sur la croissance des bactéries lactiques non levains pendant l'affinage. A. Essai 1. B. Essai 2.

to be related to moisture content (fig 2B). NSLAB reached similar numbers in all cheeses in trial 2 after 6 months ripening (fig 2B).

\section{Effect of ripening temperature}

The composition of the experimental Cheddar cheeses is shown in table IV. The salt 
Table IV. Composition ${ }^{1}$ of 1-day-old experimental cheeses ripened at different temperatures. Composition ${ }^{1}$ de fromages expérimentaux à 1 jour, affinés à différentes températures.

\begin{tabular}{lcccccc}
\hline $\begin{array}{l}\text { Ripening } \\
\text { temp }\left({ }^{\circ} \mathrm{C}\right)\end{array}$ & $\begin{array}{c}\text { Salt } \\
(\%)\end{array}$ & $\begin{array}{c}\text { Moisture } \\
(\%)\end{array}$ & $\begin{array}{c}S / M^{2} \\
(\%)\end{array}$ & $\begin{array}{c}\text { Fat } \\
(\%)\end{array}$ & $\begin{array}{c}\text { Protein } \\
(\%)\end{array}$ & $p H$ \\
\hline $\begin{array}{l}\text { Trial 1 } \\
4\end{array}$ & 1.43 & 39.6 & 3.61 & 31.0 & 24.5 & 5.23 \\
8 & 1.50 & 39.4 & 3.81 & 31.0 & 24.5 & 5.26 \\
12 & 1.47 & 40.4 & 3.64 & 31.0 & 23.9 & 5.26 \\
Trial 2 & & & & & & \\
4 & 1.27 & 38.4 & 3.31 & 30.0 & 25.1 & 5.23 \\
8 & 1.48 & 37.6 & 3.94 & 29.5 & 25.0 & 5.30 \\
12 & 1.36 & 38.3 & 3.55 & 30.0 & 24.4 & 5.26 \\
\hline
\end{tabular}

${ }^{1}$ Mean of duplicates. ${ }^{2}$ Salt-in-moisture.

${ }^{\prime}$ Moyenne de deux déterminations. ${ }^{2}$ Rapport sel/humidité.

content of the cheeses was quite low considering that the curds were salted at a level of $2.5 \%(\mathrm{w} / \mathrm{w})$. The moisture content of the cheeses in trial 1 was slightly higher than would be expected for commercial Cheddar cheese.

Starter counts in cheeses ex-press were identical within trials 1 or 2 at $1.1 \times 10^{8} \mathrm{cfu} \mathrm{g}^{-1}$ or $1.4 \times 10^{7} \mathrm{cfu} \mathrm{g}^{-1}$, respectively, but they decreased at different rates (table II). In trial 1 , the cheese ripened at $12^{\circ} \mathrm{C}$ had the lowest number of starter at all sampling times and had decreased to $2.3 \times 10^{5} \mathrm{cfu} \mathrm{g}^{-1}$ after 4 weeks; the rate of decrease of starter numbers was faster at $8{ }^{\circ} \mathrm{C}$ than at $4{ }^{\circ} \mathrm{C}$ during the very early stages of ripening (up to 3 weeks) but these cheeses had similar numbers of viable starter cells ( 7.8 and $7.3 \times 10^{5} \mathrm{cfu} \mathrm{g}^{-1}$, respectively) after 4 weeks (table II). The trend observed in cheeses in trial 1 was not repeated in trial 2 in which the cheese ripened at $8{ }^{\circ} \mathrm{C}$ had higher starter numbers than those ripened at 4 or $12{ }^{\circ} \mathrm{C}$ at all sampling times, and decreased to $3.3 \times 10^{6}, 2 \times 10^{5}$ and $4 \times 10^{5} \mathrm{cfu} \mathrm{g}^{-1}$, respectively after 4 weeks (table II).

NSLAB generally grew in these cheeses in the order $12>8>4^{\circ} \mathrm{C}$ (ie, the higher the ripening temperature, the higher the num- bers of NSLAB in the cheese) and reached $2.0 \times 10^{8}, 2.7 \times 10^{5}$ and $4.0 \times 10^{4} \mathrm{cfu} \mathrm{g}^{-1}$, respectively, in trial 1 and $2 \times 10^{7}, 1.8 \times 10^{7}$ and $1.3 \times 10^{5} \mathrm{cfu}^{-1}$, respectively, in trial 2 , after 6 months (fig $3 \mathrm{~A}$, B). The effect of temperature on the growth rate of NSLAB in cheese in trial 1 ripened at $8{ }^{\circ} \mathrm{C}$ was not as great in the corresponding cheese in trial 2 (fig $3 \mathrm{~A}, \mathrm{~B}$ ).

\section{Effect of starter strain}

The composition of the experimental cheeses is shown in table $\mathrm{V}$. The $\mathrm{pH}$ of the cheeses made with strains of Lc lactis ssp lactis ML3 or 303 was lower than those made with strains of Lc lactis ssp cremoris AM1 or AM2, with the exception of the cheese in trial 2 made with Lc lactis ssp lactis ML3. The moisture content of the cheeses was higher than expected for commercial Cheddar cheese but the salt, fat and protein contents of the cheeses were generally within normal limits.

The cheeses in both trials made with either Lc lactis ssp cremoris AM1 or AM2 had much lower starter numbers than those made with Lc lactis ssp lactis ML3 or 303 at 

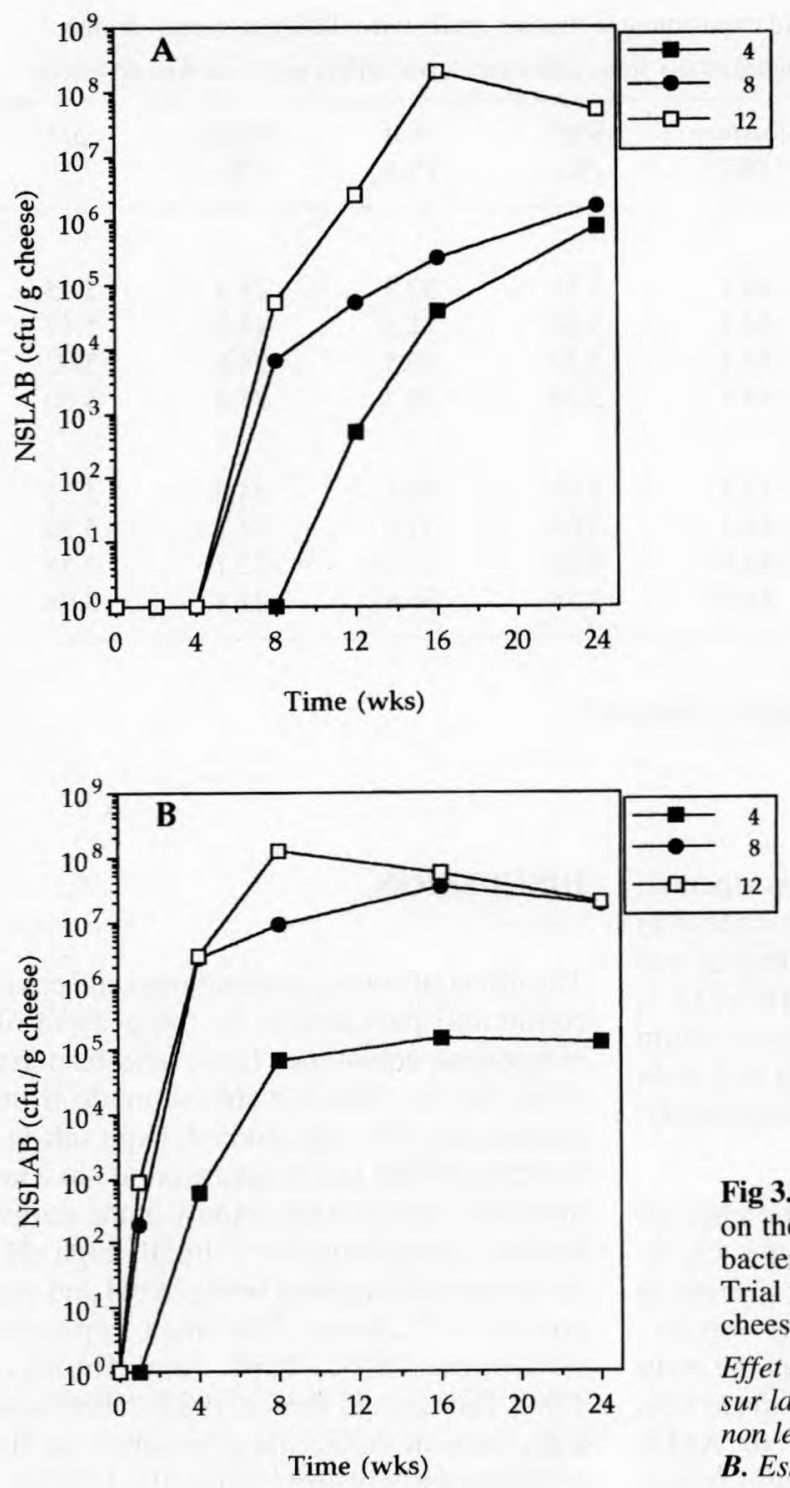

Fig 3. Effect of ripening temperature $\left({ }^{\circ} \mathrm{C}\right)$ on the growth of non-starter lactic acid bacteria during ripening. A. Trial 1 . B. Trial 2. Note: $10^{0} \approx<10 \mathrm{cfu}$ NSLAB g ${ }^{-1}$ cheese.

Effet de la température d'affinage $\left({ }^{\circ} \mathrm{C}\right)$ sur la croissance des bactéries lactiques non levains pendant l'affinage. A. Essai 1. B. Essai 2.

one day (table II). The change in numbers of AM1 and AM2 during the first 4 weeks of ripening varied unpredictably, possibly due to the growth of NSLAB on the LM17 agar, especially since the number of starter in these cheeses was quite low; NSLAB numbers reached $3.6 \times 10^{4} \mathrm{cfu} \mathrm{g}^{-1}$ in trial 1 and $1.1 \times 10^{3} \mathrm{cfu} \mathrm{g}^{-1}$ in trial 2 cheeses made with strain $\mathrm{AM} 1$ or $1.2 \times 10^{3} \mathrm{cfu} \mathrm{g}^{-1}$ in trial 1 and $5.4 \times 10^{4} \mathrm{cfu} \mathrm{g}^{-1}$ in trial 2 cheeses 
Table V. Composition ${ }^{1}$ of 1-day-old experimental cheeses made with different starter strains. Composition ${ }^{1}$ de fromages expérimentaux à 1 jour, fabriqués avec différentes souches de levain.

\begin{tabular}{lcccccc}
\hline Starter strain & $\begin{array}{c}\text { Salt } \\
(\%)\end{array}$ & $\begin{array}{c}\text { Moisture } \\
(\%)\end{array}$ & $\begin{array}{c}S / M^{2} \\
(\%)\end{array}$ & $\begin{array}{c}\text { Fat } \\
(\%)\end{array}$ & $\begin{array}{c}\text { Protein } \\
(\%)\end{array}$ & $p H$ \\
\hline Trial 1 & & & & & & \\
AM1 & 1.33 & 40.7 & 3.27 & 32.3 & 24.4 & 5.25 \\
AM2 & 1.41 & 40.5 & 3.48 & 31.5 & 24.0 & 5.17 \\
ML3 & 1.39 & 43.4 & 3.20 & 30.5 & 24.6 & 5.02 \\
303 & 1.23 & 44.1 & 2.79 & 30.3 & 23.2 & 5.00 \\
Trial 2 & & & & & & \\
AM1 & 1.53 & 42.1 & 3.63 & 30.3 & 24.0 & 5.23 \\
AM2 & 1.62 & 41.1 & 3.94 & 32.0 & 24.3 & 5.29 \\
ML3 & 1.79 & 42.0 & 4.26 & 31.0 & 22.7 & 5.35 \\
303 & 1.50 & 41.9 & 3.58 & 30.8 & 22.8 & 5.04 \\
\hline
\end{tabular}

${ }^{1}$ Mean of duplicates. ${ }^{2}$ Salt-in-moisture.

${ }^{\prime}$ Moyenne de deux déterminations. ${ }^{2}$ Rapport sel/humidité.

made with strain AM2 over this ripening period. The number of ML3 in cheese in both trials decreased by approximately one $\log$ cycle to $1.2 \times 10^{8}$ and $2.7 \times 10^{7} \mathrm{cfu} \mathrm{g}^{-1}$, respectively, while the numbers of strain 303 in both trials remained high and were $3.5 \times 10^{9}$ and $2.4 \times 10^{9} \mathrm{cfu} \mathrm{g}^{-1}$, respectively, after 4 weeks (table II).

The growth of NSLAB in the cheeses during ripening is shown in figure $4 \mathrm{~A}, \mathrm{~B}$. In general, the rate of NSLAB growth in cheese made with either Lc lactis ssp lactis ML3 or 303 was higher during the early stages of ripening than in cheese made with Lc lactis ssp cremoris AM1 or AM2. NSLAB numbers in all four cheeses in trial 1 reached similar values after 3 months and increased only slightly between 3 and 6 months (fig 4A). The same trend was found in trial 2 for the cheeses made with strains $\mathrm{AM} 1, \mathrm{AM} 2$ or ML3 but NSLAB numbers in cheese made with strain 303 were lower than in the other cheeses at both 3 and 4 months (fig 4B). NSLAB numbers in all cheeses in trial 2 were similar at 6 months.

\section{DISCUSSION}

The effect of some compositional and environmental parameters on the growth of indigenous non-starter lactic acid bacteria (NSLAB) in Cheddar cheese made from pasteurised milk was studied. High salt-inmoisture (S/M) levels appeared to have an inhibitory effect on the activity of the starter bacteria, as indicated by a slightly high $\mathrm{pH}$. An inverse relationship between $\mathrm{pH}$ and salt content of cheese has been reported (O'Connor, 1974; Turner and Thomas, 1980; Thomas and Pearce, 1982). There was a decrease in viable starter numbers in the experimental cheeses during the first few weeks of ripening. These results are in agreement with the findings of many others, including Visser (1977) and McSweeney et al (1993). The viability of starter cells during the initial stages of ripening appeared to be independent of S/M in the cheese. S/M values of $2.85-5.93 \%$ (trials 1 and 2) did not effect the growth of indigenous NSLAB during ripening; although $6.09 \% \mathrm{~S} / \mathrm{M}$ 

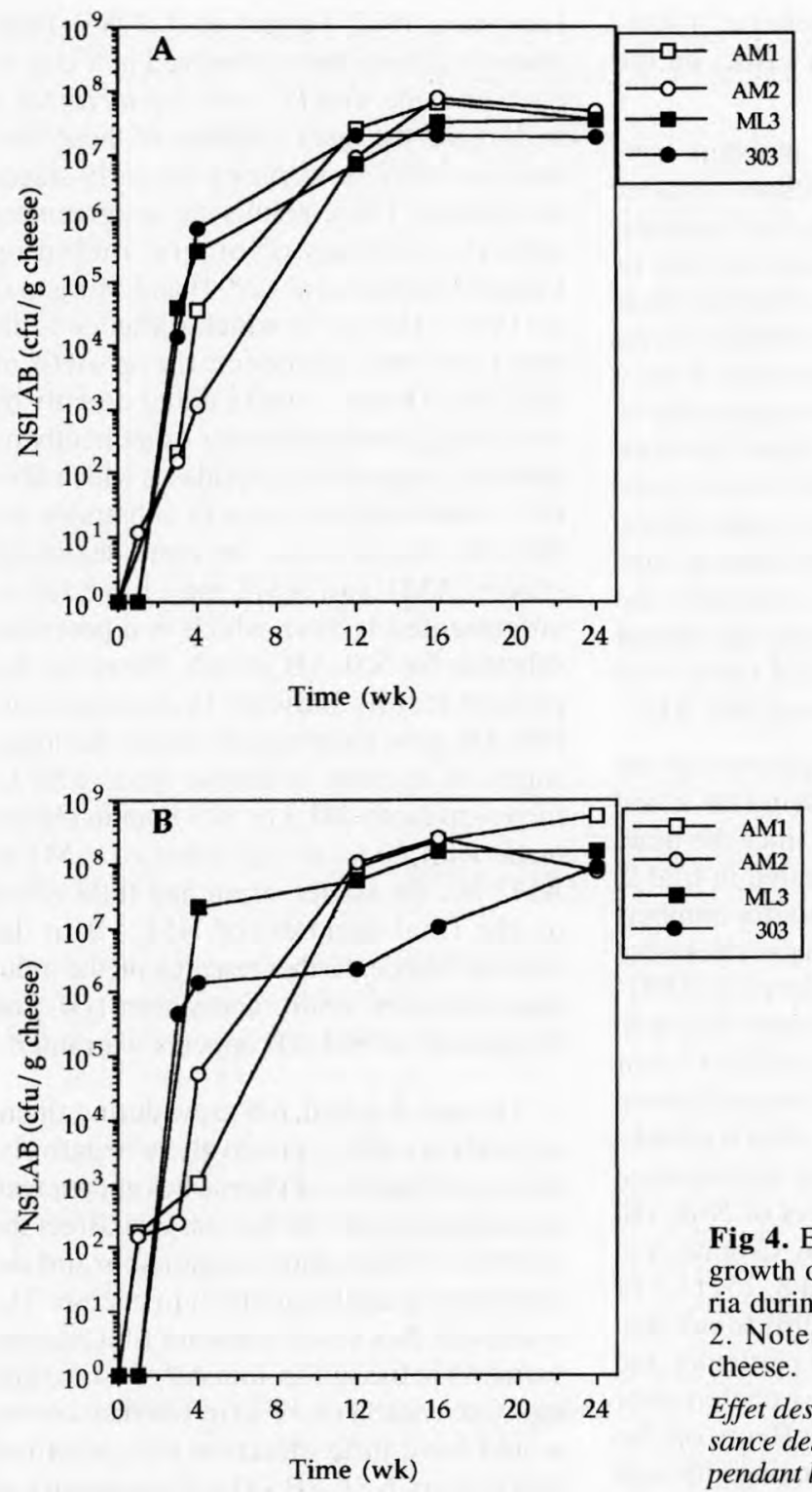

Fig 4. Effect of starter strain on the growth of non-starter lactic acid bacteria during ripening. A. Trial 1. B. Trial 2. Note: $10^{0} \approx<10 \mathrm{cfu}$ NSLAB g $\mathrm{g}^{-1}$ cheese.

Effet des souches de levain sur la croissance des bactéries lactiques non levains pendant l'affinage. A. Essai 1. B. Essai 2.

reduced the growth of NSLAB up to 4 months, the final numbers were not affected by the S/M. Jordan and Cogan (1993), who examined the salt tolerance of NSLAB ( $L b$ casei, $L b$ plantarum and $L b$ curvatus) iso- lated from commercial Irish Cheddar cheese, found that all isolates grew in the presence of $4 \% \mathrm{NaCl}$, most grew in $6 \%$ and some grew at salt concentrations as high as $10 \%$. They concluded that the levels of S/M nor- 
mally found in Cheddar cheese (ie, 4-6\%) would have little inhibitory effect on the growth of NSLAB.

Within the range studied, moisture content did not influence the decline of starter bacteria during the early stages of ripening and did not appear to influence the rate or final numbers of NSLAB although their growth in cheeses with high moisture levels had a shorter lag phase than those with a lower moisture content. It is not possible to attribute any differences found between NSLAB counts to the level of moisture alone since the method used to make cheese varying in moisture content caused substantial variations in other compositional factors, especially $\mathrm{pH}$ (and hence the amount of unfermented lactose), and these may affect the growth of indigenous NSLAB.

The effect of ripening temperature on the decline of starter numbers during the initial stages of ripening is unclear since the trend found in trial 1 was not repeated in trial 2 . Law et al (1979) found that starter numbers decreased more slowly in cheese ripened at 8 than at $13{ }^{\circ} \mathrm{C}$ while Cromie et al $(1987)$ reported that starter counts were lower in cheese stored at $8{ }^{\circ} \mathrm{C}$ than at $15,17.5$ or $20^{\circ} \mathrm{C}$. NSLAB numbers in cheeses ripened at $4{ }^{\circ} \mathrm{C}$ were quite low even after 6 months and increasing the ripening temperature resulted in increased numbers of NSLAB. Similar results were found by Cromie et al (1987) for cheeses ripened at $8,15,17.5$ or $20^{\circ} \mathrm{C}$. Folkertsma et al (1996) found that ripening temperature and, in particular, the rate at which the cheese was cooled after pressing had considerable effects on the growth of NSLAB during ripening although ripening temperature $\left(8,12\right.$ or $\left.16^{\circ} \mathrm{C}\right)$ had little effect on the number of NSLAB after 9 months.

Numbers of starter bacteria in cheeses made using Le lactis ssp cremoris AM1 or AM2 were low at 1 day, possibly due to the fact that these strains are quite sensitive to cooking temperature and salt (Martley and
Lawrence, 1972; Fedrick et al, 1986). High starter numbers were observed at 1 day in cheeses made with Lc lactis ssp lactis ML3 or 303 and the rate of decline of these bacteria was very slow during the early stages of ripening. These results are in agreement with the findings of others, including Chapot-Chartier et al (1994) and Morgan et al (1995). The rate at which starter cells die and lyse may influence the growth of NSLAB (Thomas, 1987), either directly by providing growth substrates or indirectly by releasing intracellular peptidases which liberate amino acids as growth substrates for NSLAB. Furthermore, the rapid decline of strains AM1 and AM2 may have led to unfermented lactose which is a potential substrate for NSLAB growth. However, the present results indicate that indigenous NSLAB grew more rapidly during the initial stages of ripening in cheese made with $L c$ lactis ssp lactis ML 3 or 303 than in cheese made with Le lactis ssp cremoris AM1 or AM2 but the starter strain had little effect on the final numbers of NSLAB in the cheeses. Hence, further research on the influence of starter strain (and starter lysis) on the growth of NSLAB appears warranted.

The fact that NSLAB grow during ripening and may affect, positively or negatively, the overall quality of cheese has encouraged investigation into the factors that affect the growth of these micro-organisms and the substrates available to them in cheese. The results of this study indicate that normal variation in the salt-in-moisture $(4-6 \%)$ and moisture content $(<39 \%)$ of Cheddar cheese would have little effect on the growth of indigenous NSLAB. The temperature at which cheese is ripened influences the rate of growth of NSLAB and this should be taken into account when suggesting temperature as a means of accelerating the ripening process. The initial growth of indigenous NSLAB appears to be starterdependent but further research is required on this subject. 


\section{ACKNOWLEDGMENTS}

This project was funded in part from structural funds from the Food Sub-programme of the EU Industry programme.

\section{REFERENCES}

Chapot-Chartier MP, Deniel C, Rousseau M, Vassal L, Gripon JC (1994) Autolysis of two strains of Lactococcus lactis during cheese ripening. Int Dairy $J 4,251-269$

Cromie SJ, Giles JE, Dulley JR (1987) Effect of elevated ripening temperature on the microflora of Cheddar cheese. J Dairy Res 54, 69-76

Fedrick IA, Cromie SJ, Dulley JR (1986) The effects of increased starter populations, added neutral proteinase and elevated temperature storage on Cheddar cheese manufacture and maturation. NZ J Dairy Sci Technol 21, 191-203

Folkertsma B, Fox PF, McSweeney PLH (1996) Accelerated ripening of Cheddar cheese at elevated temperatures. Int Dairy J 6, 1117-1134

Fox PF (1963) Potentiometric determination of salt in cheese, J Dairy Sci 46, 744-745

IDF (1964) Determination of the protein content of processed cheese products (Standard 25). International Dairy Federation, Brussels

IDF (1982) Cheese and processed cheese - Determination of total solids content (Standard 4a). International Dairy Federation, Brussels

IIRS (1955) Determination of the percentage of fat in cheese (Irish Standard 69). Institute for Industrial Research and Standards, Dublin

Jordan KN, Cogan TM (1993) Identification and growth of non starter lactic acid bacteria in Irish Cheddar cheese. Irish J Agric Food Res 32, 47-55

Kanawjia SK, Nageswara Rao K, Singh S, Sabikhi L (1993) Role of lactobacilli in cheese - A review. Indian J Dairy Sci 46, 187-197

Khalid NM, Marth EH (1990) Lactobacilli - Their enzymes and role in ripening and spoilage of cheese: A review, J Dairy Sci 73, 2669-2684

Kleter G (1977) The ripening of Gouda cheese made under strictly aseptic conditions. 2 . The comparison of the activity of different starters and the influ- ence of certain Lactobacillus strains. Neth Milk Dairy J 31, 177-187

Law BA, Hosking ZD, Chapman HR (1979) The effect of some manufacturing conditions on the development of flavour in Cheddar cheese. J Soc Dairy Technol 32, 87-90

Martley FG, Crow VL (1993) Interactions between non-starter microorganisms during cheese manufacture and ripening. Int Dairy J 3, 461-483

Martley FG, Lawrence RC (1972) Cheddar cheese flavour. II. Characteristics of single strain starters associated with good or poor flavour development. NZ J Dairy Sci Technol 7, 38-44

McSweeney PLH, Fox PF, Lucey JA, Jordan, KN, Cogan TM (1993) Contribution of the indigenous microflora to the maturation of Cheddar cheese. Int Dairy J 3, 613-634

Morgan S, O'Donovan C, Ross RP, Hill C, Fox PF (1995) Significance of autolysis and bacteriocininduced lysis of starter cultures in Cheddar cheese ripening. In: Proc, 4th Cheese Symposium (Cogan TM, Fox PF, Ross RP, eds) Teagasc, Fermoy Co, Cork, 51-60

O'Connor CB (1974) The quality and composition of Cheddar cheese. Effect of various rates of salt addition. III. Irish Agric Creamery Rev 27, 11-13

Peterson SD, Marshall RT (1990) Nonstarter lactobacilli in Cheddar cheese: A review. $J$ Dairy $S c i$ $73,1395-1410$

Rogosa M, Mitchell JA, Wiseman RF (1951) A selective medium for the enumeration of oral and faecal lactobacilli. J Bacteriol 62, 132-133

Terzaghi BE, Sandine WE (1975) Improved media for lactic streptococci and their bacteriophages. Appl Microbiol 29, 807-813

Thomas TD (1987) Cannibalism among bacteria found in cheese. NZ J Dairy Sci Technol 22, 215-219

Thomas TD, Pearce KN (1982) Influence of salt on lactose fermentation and proteolysis in Cheddar cheese. NZ J Dairy Sci Technol 16, 253-259

Turner KW, Thomas TD (1980) Lactose fermentation in Cheddar cheese and the effect of salt. NZ J Dairy Sci Technol 15, 265-276

Visser FMW (1977) Contribution of enzymes from rennet, starter bacteria and milk to proteolysis and flavour development in Gouda cheese. I. Description of cheese and aseptic cheesemaking techniques. Neth Milk Dairy J 31, 120-133 